\title{
Morphology Change and Carburization Characteristic of Iron Ore- Coal Composite During Reduction under a Simulated Condition of Blast Furnace
}

\author{
Tsung-Yen HUANG, ${ }^{1 *}$ Daisuke MARUOKA, ${ }^{2)}$ Taichi MURAKAMI ${ }^{21}$ and Eiki KASAI ${ }^{2)}$ \\ 1) Iron \& Steel Research and Development Department, China Steel Corporation, No. 1, Chung Kang Rd., Hsiao Kang, \\ Kaohsiung, 81233 Taiwan. \\ 2) Graduate School of Environmental Studies, Tohoku University, 6-6-02, Aramaki-Aza Aoba, Aoba-ku, Sendai, 980-8579 \\ Japan.
}

(Received on April 2, 2019; accepted on May 27, 2019)

\begin{abstract}
Ironmaking process by Blast Furnace (BF) method contributes about $70 \%$ of $\mathrm{CO}_{2}$ emission and energy consumption in steel works. To aim at the sustainable development and environmental protection, decreasing $\mathrm{CO}_{2}$ emission and energy consumption is always an indispensable task. Using iron ore-coal composite as the raw material of BF is a promising way to mitigate the above issue.

In this study, we conducted an experiment procedure which is to simulate the reduction of an iron orecoal composite travelling from the top zone to the cohesive zone of BF. Reduction behavior, morphology changes and carburization characteristic of the composites with the variables of $\mathrm{C} / \mathrm{O}$ (Carbon to Oxygen) ratio were investigated.

As $\mathrm{C} / \mathrm{O}$ ratio was increased from 0 to 0.6 , the reduction rate of composite was accordingly enhanced. It was found that the composite is swelling severely when $\mathrm{C} / \mathrm{O}$ ratio was lower than 0.4 . The swelling occurred in the temperature range from $800^{\circ} \mathrm{C}$ to $1100^{\circ} \mathrm{C}$ which was just under the stage of reduction from wustite to iron. The composite is shattering obviously starting from $1160^{\circ} \mathrm{C}$ when $\mathrm{C} / \mathrm{O}$ ratio was higher than 0.4. It is because the remained free carbon is surplus in reduced iron, causing shattering and powdering. Hence, $\mathrm{C} / \mathrm{O}=0.4$ was suggested to the composite for being charged into BF.
\end{abstract}

KEY WORDS: iron ore-coal composite; ironmaking; carbothermic reduction; reduction; blast furnace; carburization; low carbon emission; melting of iron.

\section{Introduction}

With respect to ironmaking process, blast furnace $(\mathrm{BF})$ currently is the most important reactor among the global steel industry. Although there are alternative ironmaking processes such as Midrex, Corex or Finex method, BF will still remain to be popular many years to come because of its productivity and energy efficiency. Accordingly, decreasing the reducing agent in BF process is an indispensable task. The usage amount of reducing agent in BF is based on carbon which is concerned not only energy consumption but also $\mathrm{CO}_{2}$ emission. Nowadays, the energy efficiency and $\mathrm{CO}_{2}$ emission is close to nearly optimum condition by means of conventional raw materials and operation due to many researches and developments.

According to RIST diagram and $\mathrm{Fe}-\mathrm{C}-\mathrm{O}$ diagram, it is possible to improve a further step of $\mathrm{CO}$ gas utilization efficiency by lowing the temperature at thermal reserve zone (TRZ) of BF ${ }^{1-3)}$ Using high reactivity coke or mixing small coke in ore layers can lower the starting temperature of the

* Corresponding author: E-mail: 172833@mail.csc.com.tw

DOI: https://doi.org/10.2355/isijinternational.ISIJINT-2019-178 solution loss reaction, which is nearly consistent with the TRZ temperature. ${ }^{4,5)}$ In TRZ FeO is under reduction and the $\mathrm{CO} /\left(\mathrm{CO}+\mathrm{CO}_{2}\right)$ concentration ratio is approaching to the equilibrium curve of $\mathrm{FeO}-\mathrm{Fe}$ in $\mathrm{Fe}-\mathrm{C}-\mathrm{O}$ diagram. Lowering TRZ temperature means that $\mathrm{FeO}$ reduction temperature is also decreased and accordingly $\mathrm{CO}$ gas utilization is shifted to higher efficiency side.

The purpose of using high reactivity coke or small coke mixing in ore layers is to enhance the reduction reaction of iron ores. When small coke is mixed in iron ore layer, the distance between ore and small coke particles is absolutely shortened. Operation of commercial BF in Kakogawa Works, Kobe in Japan, showed that when the mixing rate of small coke was increased from $30 \mathrm{Kg} / \mathrm{THM}$ to $100 \mathrm{Kg}$ / THM, the TRZ temperature was decreased $50^{\circ} \mathrm{C}$. Moreover, the $\mathrm{CO}$ utilization was shifted to high efficiency side. ${ }^{6}$ Therefore, mass transfer between reducing agent and iron ore is a crucial factor for the reduction of iron oxide in the shaft part of BF. Moreover, the iron ore-carbonaceous composite is recognized as a micro-reactor for conducting the reduction of iron oxide because the distance between iron oxide and carbonaceous material is in the range of micrometer. ${ }^{7)}$ Laboratory scale experiment on iron ore- 
carbon composite had presented the starting temperature of endothermic reaction, which is nearly the same with the TRZ temperature in BF, was lowered ${ }^{4)}$ and the gasification reaction, which is recognized as solution loss reaction, was improved. ${ }^{8)}$ In practically, it was demonstrated that the TRZ temperature and the usage amount of reducing agent was lowered, ${ }^{5,9)}$ as well the gas composition was toward to the equilibrium curve of Boudouard equilibrium when charging the iron ore-carbon composite into $\mathrm{BF}^{5}$ )

While the benefit using iron ore-carbon composite as raw material of $\mathrm{BF}$ is confirmed, in order to promoting the application and increasing the usage amount, the fundamental investigations are still propagating. Since the iron ore-carbon composite is charged into $\mathrm{BF}$, some properties are needed to be concerned. Firstly, it is anticipated that the reduction of iron ore can be speeded up and the reduction temperature can be lowered. As iron oxide is reduced to metallic iron, the carburization reaction is become important because carbon dissolution in iron leads to decrease the melting point of iron. It is benefit to the energy efficiency on the operation of BF. Besides, the strength of iron ore-carbon is the same important with other burden materials such as sinter, pellet or lump ore during the reduction period. Murakami et al. ${ }^{10)}$ reported that applying two different types of carbonaceous materials on composite are able to improve not only the reduction but also the carburization. One type of carbonaceous is coal or charcoal, which is suitable for the reducing agent because it can generate the reducing gases at lower temperature. The other one carbonaceous is graphite or coke which can be used for carburization due to having lower reactivity with $\mathrm{CO}_{2}$. Kowitwarangkul et al. ${ }^{11)}$ discovered that the starting temperature of solution loss reaction was decreased by more than $100 \mathrm{~K}$ compared to the conventional BF by conducting the experiment of composite in TG/DTA. Park et al. ${ }^{12)}$ used an in situ visualization apparatus to observe the reaction during the temperature range of $1350^{\circ} \mathrm{C}$ to $1500^{\circ} \mathrm{C}$ under inert gas atmosphere. They found that the composite with the conditions of low carbon addition and high $\mathrm{Al}_{2} \mathrm{O}_{3}$ content had relative high strength. In contrast, the composite with high carbon addition of $20 \%$ and high $\mathrm{SiO}_{2}$ content was completely shattered after reduction. Most of previous studies conduct the reduction of composite under inert gas atmosphere because the composite is a gas generator. However, as the aim of the study is on the new raw material of $\mathrm{BF}$, the experimental conditions of gas atmosphere and temperature are needed to follow the condition of conventional BF. Although reference ${ }^{7)}$ had some discussion on reduction behavior, but the $\mathrm{CO} / \mathrm{CO}_{2}$ atmosphere was under a constant ratio. Besides, the study on combination of reduction behavior, morphology changes and carburization characteristic is very few.

Therefore, in this study we conducted an experiment procedure which was to simulate the reduction of an iron ore-coal composite passing from the top zone of BF to approaching the cohesive zone of BF. Meanwhile, the off gas composition was analyzed to calculate gas generation, gas consumption and furthermore the reduction degree of composite. The shape of composite was recorded simultaneously by camera during the reduction to identify the changes of morphology. Finally, the microstructure and carbon content in the reduced iron and in metallic iron were inspected. The behavior of reduction, morphology and carburization in the variable of $\mathrm{C} / \mathrm{O}$ ratio of composite were discussed.

\section{Experimental Method}

Chemical composition of iron ore used in this study was showed in Table 1. Benchmark material was sinter made by China Steel Corporation. Iron ore concentrate, which is usually called as pellet feed fines, was used in regular experiment. The average particle size of the concentrate was $26.4 \mu \mathrm{m}$. The amount of $10 \%, 50 \%$ and $90 \%$ of iron ore concentrate were below the particle size of $3.4 \mu \mathrm{m}, 20.9 \mu \mathrm{m}$ and $55.6 \mu \mathrm{m}$, respectively. The reductant was Pulverized Coal (PC) which was usually injected together with hot air in tuyer of blast furnace. Composition of PC including volatile matter (VM), carbon content and chemical composition of the ash were showed in Table 2.

A ratio of $\mathrm{C} / \mathrm{O}$, the molar ratio of fixed carbon in $\mathrm{PC}$ to reducible oxygen in iron ore, was defined for mixing iron ore and PC powder together. Then iron ore and PC powders were well mixed in dry condition without adding water. Next, the mixture was put in a die with diameter of $10 \mathrm{~mm}$ and then was press-shaped by a hydraulic presser under a pressure of $9.8 \times 10^{7} \mathrm{~Pa}$ in room temperature. The tablet sample was obtained.

The experimental apparatuses were showed in Fig. 1. Figure 1(a) is a vertical infrared image furnace equipped with an infrared gas analysis system and a gas chromatography (GC) which can continuously measure the concertation of $\mathrm{CO}, \mathrm{CO}_{2}, \mathrm{H}_{2}, \mathrm{H}_{2} \mathrm{O}, \mathrm{CH}_{4}, \mathrm{C}_{2} \mathrm{H}_{4}, \mathrm{C}_{2} \mathrm{H}_{6}$ and $\mathrm{N}_{2}$ in the outlet gas. ${ }^{13)}$ The study on reduction behavior of iron ore-coal composite was conducted by this apparatus. The composite tablet was put in the center of furnace and a thermocouple was placed on the top of tablet to measure the reaction temperature. Before beginning of the experiment, the air in the

Table 2. Composition of reductant used in this study (mass $\%$ ).

\begin{tabular}{|c|c|c|c|c|c|c|c|c|c|}
\hline \multicolumn{10}{|c|}{ Reductant: Pulverized Coal (PC) } \\
\hline \multicolumn{4}{|c|}{ Proximate analysis (ad) } & \multicolumn{5}{|c|}{ Ultimate Analysis (ad) } & \\
\hline $\mathrm{H}_{2} \mathrm{O}$ & VM & Ash & $\mathrm{FC}$ & T.C & $\mathrm{H}$ & $\mathrm{S}$ & $\mathrm{N}$ & $\mathrm{O}$ & \\
\hline 1.29 & 20.49 & 8.73 & 69.48 & 81.74 & 4.06 & 0.34 & 1.50 & 2.38 & \\
\hline \multicolumn{10}{|c|}{ Ash Composition (in ash) } \\
\hline $\mathrm{SiO}_{2}$ & $\mathrm{Al}_{2} \mathrm{O}_{3}$ & $\mathrm{Fe}_{2} \mathrm{O}_{3}$ & $\mathrm{TiO}_{2}$ & $\mathrm{CaO}$ & $\mathrm{MgO}$ & $\mathrm{Na}_{2} \mathrm{O}$ & $\mathrm{K}_{2} \mathrm{O}$ & $\mathrm{P}_{2} \mathrm{O}_{5}$ & $\mathrm{MnO}$ \\
\hline 51.48 & 27.29 & 8.58 & 1.28 & 3.93 & 1.47 & 0.83 & 1.01 & 2.21 & 0.07 \\
\hline
\end{tabular}

Table 1. Chemical composition of iron ore used in this study (mass\%).

\begin{tabular}{ccccccccccc}
\hline Ore name & $\mathrm{T} . \mathrm{Fe}$ & $\mathrm{FeO}$ & $\mathrm{CaO}$ & $\mathrm{MgO}$ & $\mathrm{Al}_{2} \mathrm{O}_{3}$ & $\mathrm{SiO}_{2}$ & $\mathrm{TiO}_{2}$ & $\mathrm{LOI}$ & $\mathrm{K}_{2} \mathrm{O}$ & $\mathrm{Na}_{2} \mathrm{O}$ \\
\hline Sinter & 56.54 & 6.25 & 9.82 & 1.55 & 1.69 & 5.18 & - & - & - & - \\
Iron ore concentrate & 67.13 & 0.21 & 0.08 & 0.02 & 0.66 & 2.73 & 0.09 & 0.70 & 0.005 & 0.007 \\
\hline
\end{tabular}




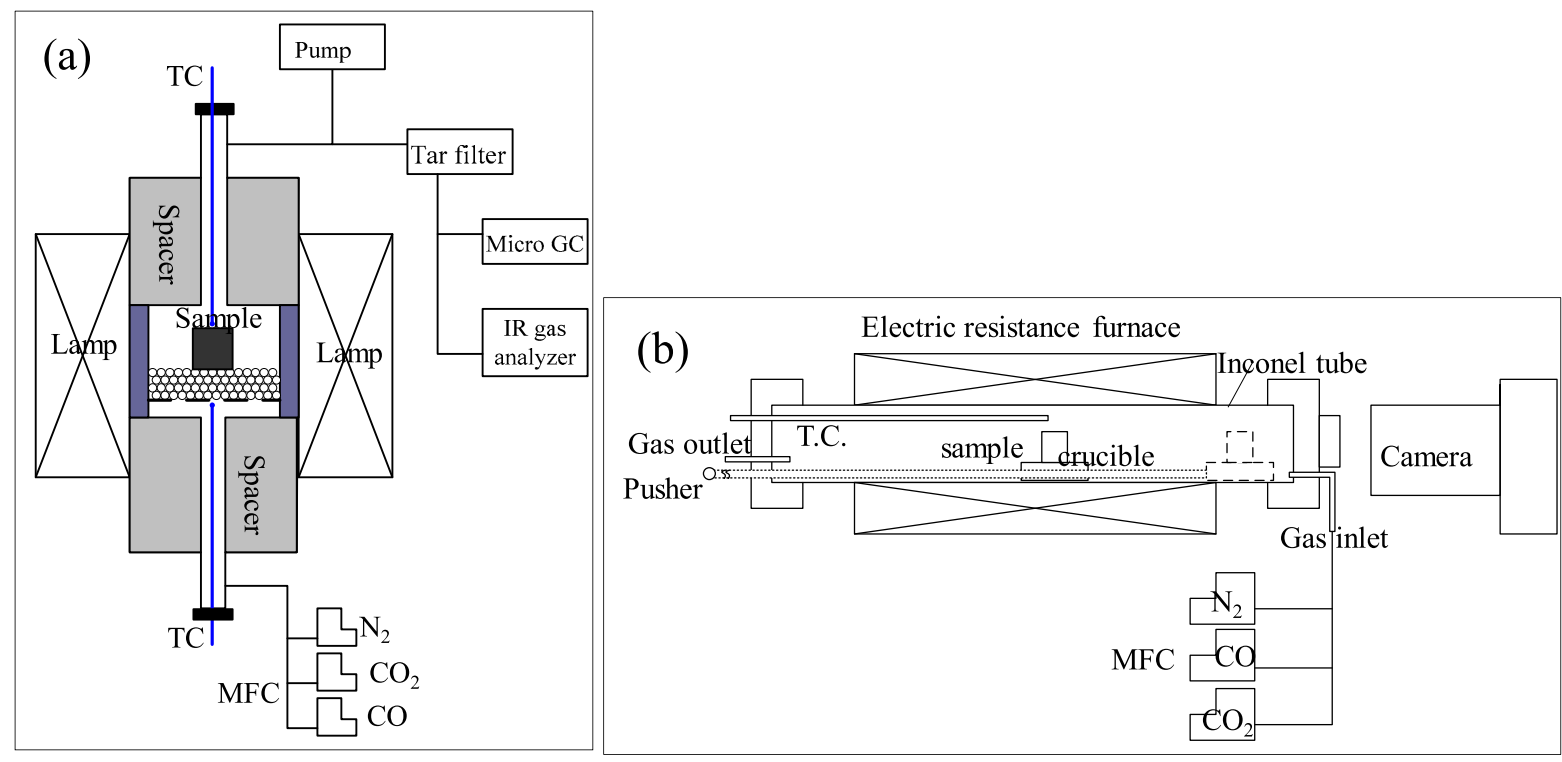

Fig. 1. Schematic diagram of experimental apparatuses: (a) Vertical infrared image furnace, (b) Horizontal electric resistance furnace. (Online version in color.)

furnace was evacuated and then a fresh mixture of $50 \% \mathrm{~N}_{2} /$ $\mathrm{CO} / \mathrm{CO}_{2}$ gas was introduced at a constant total flow rate of $1000 \mathrm{ml} / \mathrm{min}$. The sample was heated by a heating profile with its gas concentration profile shown in Fig. 2. This corresponded heating and gas concentration profile was considered to simulate the condition of an iron-bearing material passing from the top zone of $\mathrm{BF}$ to near the cohesive zone of BF. As soon as the experiment was to the end, switched the gas to $100 \% \mathrm{~N}_{2}$ and shut off the power of furnace. The cooling rate was roughly $10^{\circ} \mathrm{C} / \mathrm{s}$ from $1300^{\circ} \mathrm{C}$ to $1000^{\circ} \mathrm{C}$.

On the other hand, we carried out the direct observation experiment on morphology changes by a horizontal electric resistance furnace shown in Fig. 1(b). The experimental procedure of horizontal furnace was almost the same with that of infrared image furnace. The condition of heating and gas concentration profile was also base on that of Fig. 2. Besides, we placed a camera at the end of tube, where was also the upstream side of gas flowing direction, for recording the morphology changes of composite sample from $700^{\circ} \mathrm{C}$ to $1300^{\circ} \mathrm{C}$. As the furnace was heated to $1300^{\circ} \mathrm{C}$, the sample was quickly pushed form center to upstream of tube for terminating the reduction and cooling down by using a pusher bar.

Table 3 lists the sample preparation and experimental conditions. Three benchmark experiments were carried out using sinter as raw material, the tablet of iron ore concentrate, and iron ore-coal composite reduced under $50 \% \mathrm{~N}_{2} /$ $\mathrm{Ar}$ atmosphere. The main independent variables were $\mathrm{C} / \mathrm{O}$ ratio.

Reduction degree (RD) of sample was calculated by the following equation:

$\mathrm{RD} \%=$

$\frac{M_{\mathrm{CO}}+M_{\mathrm{CO}_{2}}+M_{\mathrm{H}_{2} \mathrm{O}}-M_{\mathrm{LOI}}-M_{V M}-M_{\text {introducing } \mathrm{CO}}-M_{\text {introducing } \mathrm{CO}_{2}}}{M_{\text {total reducible } \mathrm{O}}} \times 100$

Here, $\mathrm{M}_{\mathrm{CO}}, \mathrm{M}_{\mathrm{CO}_{2}}, \mathrm{M}_{\mathrm{H}_{2} \mathrm{O}}$ were the molar amounts of oxygen atom in $\mathrm{CO}, \mathrm{CO}_{2}$ and $\mathrm{H}_{2} \mathrm{O}$ gases, respectively, measured by GC. The measured gases contained not only the gas

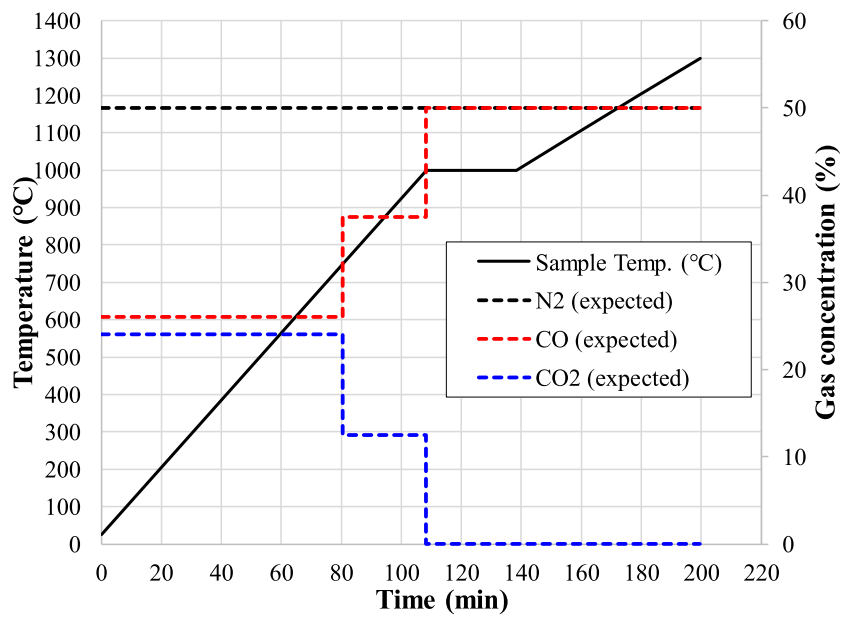

Fig. 2. Corresponding heating profile with gas concentration. (Online version in color.)

Table 3. Sample preparation and experimental conditions.

\begin{tabular}{ccccc}
\hline Group name & Sample name & Ore & C/O & Basicity \\
\hline \multirow{2}{*}{$\begin{array}{c}\text { Benchmark } \\
\text { experiment }\end{array}$} & $\mathrm{B} 1$ & Sinter & - & 1.90 \\
& $\mathrm{~B} 2$ & Concentrate & 0.0 & 0.04 \\
& $\mathrm{~B} 3^{*}$ & Concentrate & 0.4 & 0.04 \\
\hline \multirow{2}{*}{$\begin{array}{c}\text { Effect of } \\
\text { C/O ratio }\end{array}$} & $\mathrm{C} 2$ & Concentrate & 0.0 & 0.04 \\
& $\mathrm{C} 3$ & Concentrate & 0.2 & 0.04 \\
& $\mathrm{C} 4$ & Concentrate & 0.6 & 0.04 \\
& $\mathrm{C} 5$ & Concentrate & 0.8 & 0.04 \\
\hline
\end{tabular}

B3* experiment was under $50 \% \mathrm{~N}_{2} / \mathrm{Ar}$ atmosphere.

generated from the composite sample but also the introduced gas. $M_{V M}$ and $M_{L O I}$ were the molar amount generated from volatile matter of coal and from LOI of iron ore,

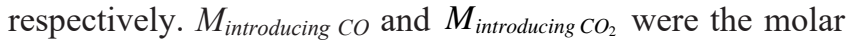
amounts of oxygen atom from the introduced $\mathrm{CO}$ and $\mathrm{CO}_{2}$ gas. $M_{\text {total reducible } O} O$ was the molar amount originally existed 
in iron ore.

The projected area of composite sample was measured base on the video recorded by camera. Further, the ratio of projected area change (AC) between initial projected area $\left(P_{\text {area }_{T=R T}}\right)$ and the projected area under reaction with temperature $\left(P \cdot{ }_{\cdot \text { area }_{T=T_{i}}}\right)$ were calculated. The calculation equation was below.

$$
\begin{aligned}
& \text { Ratio of projected area changes }(\%)= \\
& \frac{\text { P. } \text { area }_{T=T_{i}}-P . \text { area }_{T=R T}}{\text { P. } \text { area }_{T=R T}} \times 100
\end{aligned}
$$

The positive and negative values of projected area change state for the swelling and shrinkage of composite, respectively.

The as-reduced iron samples were subject to the microstructure inspection by scanning electron microscope (SEM), identification of chemical composition by energy dispersive X-ray spectroscopy (EDX), and measurement of remained carbon by the infrared absorption method. Samples for analysis of remained carbon were needed to be pulverized. Noted that in order to measure the carbon content both in as-reduced iron and in metallic iron, the samples were conducted the separation procedure as following. ${ }^{10)}$ Firstly, the sample was cooled in liquid nitrogen and then was quickly pulverized by a mortar. One part of powder was taken to measure its carbon content which was recognized as total carbon amount in the reduced iron. Next, distilled water was added in the other part of powder to purge the most part of free carbon. Further, floated fine particles were poured away by adding ethanol in the powder under the shaking of ultrasonic bath. After repeating this treatment few times and removing all floating fine particles, the metallic iron sample was obtained. The carbon content measured in this stage was recognized as dissolved carbon amount in metallic iron.

\section{Results and Discussion}

\subsection{Benchmark Experiment}

In order to compare the reduction behavior and morphology changes between iron ore-coal composite with the conventional raw material of $\mathrm{BF}$, benchmark experiments of sinter particle (B1) and iron ore concentrate tablet (B2) were carried out. Here, concentrate tablet was without adding carbonaceous material and binder. Figure 3 is the changes in reduction degree and the ratio of $\mathrm{CO} /\left(\mathrm{CO}+\mathrm{CO}_{2}\right)$ with temperature on the phase diagram of $\mathrm{Fe}-\mathrm{C}-\mathrm{O}$ system from the experiment of sinter (B1) and concentrate tablet (B2). The $\mathrm{CO} /\left(\mathrm{CO}+\mathrm{CO}_{2}\right)$ ratio was adjusted by introducing $\mathrm{CO}$ and $\mathrm{CO}_{2}$ gas and Boudouard equilibrium curve were also plotted on Fig. 3 for reference. The reduction rate of $\mathrm{B} 2$ sample is significantly higher than that of $\mathrm{B} 1$. Noted that the curve of $\mathrm{CO} /\left(\mathrm{CO}+\mathrm{CO}_{2}\right)$ ratio of $\mathrm{B} 2$ exists a peak at $450^{\circ} \mathrm{C}$ and passes through the equilibrium curve of $\mathrm{FeO}-\mathrm{Fe}$ at $850^{\circ} \mathrm{C}$. At the temperature of $450^{\circ} \mathrm{C}$ and $850^{\circ} \mathrm{C}$, the reduction degree is about 12 and $32 \%$, which are identified as the beginning point of reduction of magnetite and wustite, respectively. In contrast, $\mathrm{B} 1$ sample needs higher temperature and higher $\mathrm{CO} /\left(\mathrm{CO}+\mathrm{CO}_{2}\right)$ ratio to achieve the same reduction degree with B2. Ratio of projected area changes with reduction

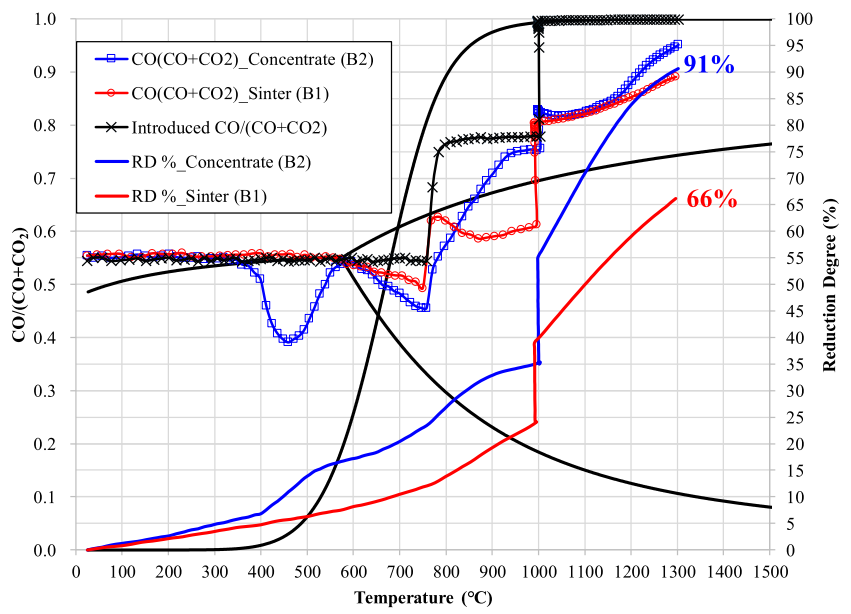

Fig. 3. Changes in reduction degree and the ratio of $\mathrm{CO} /$ $\left(\mathrm{CO}+\mathrm{CO}_{2}\right)$ with temperature on the phase diagram of $\mathrm{Fe}-$ $\mathrm{C}-\mathrm{O}$ system. (Online version in color.)

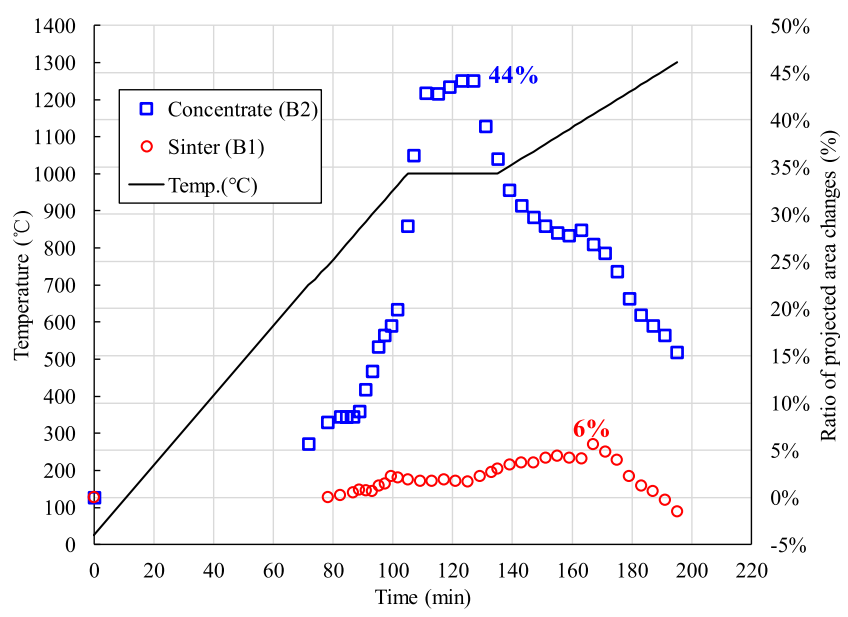

Fig. 4. Ratio of projected area changes with reduction temperature. (Online version in color.)

temperature of B1 and B2 samples are drawn in Fig. 4. B2 sample appeared swelling during the reduction. The significantly beginning point of swelling is at about $850^{\circ} \mathrm{C}$ and the decrement of swelling is at the end of $1000^{\circ} \mathrm{C}$ duration. The reduction degree in temperature range from $850^{\circ} \mathrm{C}$ to end of $1000{ }^{\circ} \mathrm{C}$ duration is $32 \%$ to $55 \%$. On the other hand, $\mathrm{B} 1$ just has a slight swelling of $6 \%$. The swelling is from end of $1000^{\circ} \mathrm{C}$ duration to $1150^{\circ} \mathrm{C}$, which can be reflected to the reduction degree of $35 \%$ to $55 \%$. It revealed that the swelling of both B1 and B2 samples occurred in the range of about $32 \%$ to $55 \%$ of reduction degree where part of metallic iron was just reduced from $\mathrm{FeO}$.

Figure 5 shows the microstructure of reduced sample a) $\mathrm{B} 1$ and b) B2. Figure 5(a) shows the interface between FeO and reduced iron. Right bottom side is toward to the core of sample. Main phase is FeO. Left top side is close to surface of sample where as-reduced iron and under reduction of $\mathrm{FeO}$ exist. The large grains of $\mathrm{FeO}$ such as right bottom structure were gradually reduced into metallic iron and were left small grains of $\mathrm{FeO}$ such as left top structure. Meanwhile, as-reduced iron particles were merging together into large grain. In addition, the slag consisted of $\mathrm{Fe}-\mathrm{Si}-\mathrm{Ca}-\mathrm{Al}$ oxide was the continuous phase in the reduced iron area. B2 image shows the as-reduced iron particles agglomerated together. 

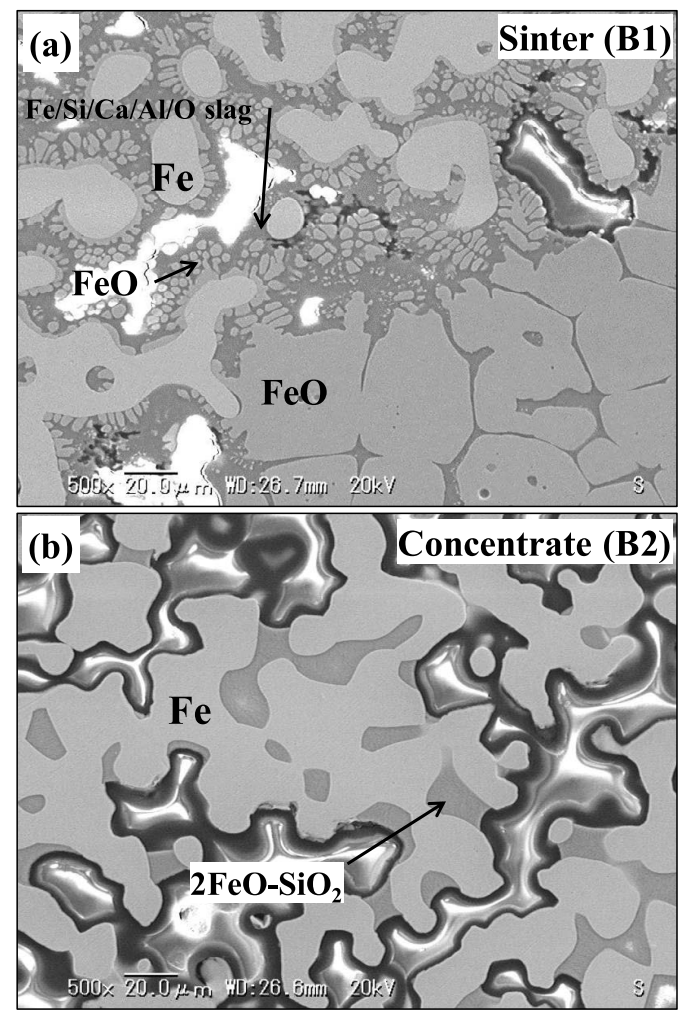

Fig. 5. Microstructures of reduced samples from a) sinter (B1) and b) concentrate (B2).

The melting phase filled in the pore of reduced iron was identified as Fayalite $\left(2 \mathrm{FeO}-\mathrm{SiO}_{2}\right)$ by EDX.

On the basis of the information from $\mathrm{CO} /\left(\mathrm{CO}+\mathrm{CO}_{2}\right)$ concentration ratio, reduction rate and microstructure, the reduction behaviors of $\mathrm{B} 1$ and $\mathrm{B} 2$ were obviously different. In addition to the difference of mineral compositions between sinter and concentrate, a possible reason causing different reduction behaviors is proposed here. Sinter is a densified material made from small particle iron ore and flux. The liquid phase such as calcium ferrite binds iron ore particles together. Therefore, reduction of B1 occurred from the surface and then propagated to the core. The reaction resistance is proposed on the diffusion of reductant gas penetrating toward the core of sinter. On the other hand, B2 made from iron ore concentrate has porous structure and larger specific surface area because there is no binding matrix among iron ore particles. Moreover, the structure of reduced sample was uniform over the whole sample showed like Fig. 5(b). Suppose that gas diffusion is not the limited factor. As long as the ore particles were heated to reducible temperature, the reduction was induced in the whole tablet. This is the suggested reason in higher reduction rate of B2. However, as reduction occurred at all individual iron ore particles at the same time, it may generate higher stress inside the tablet and may cause the swelling. Moreover, in some of our quenched experiments at $1000^{\circ} \mathrm{C}$, not shown in this report, it was easy to see the iron micro-whiskers grown form the $\mathrm{FeO}$ particles inside the as-reduced sample under the observation of SEM. Meanwhile, the in-situ measurement of reduction degree and visual observation revealed the swelling took place under the reduction stage of FeO. Therefore, the growth of iron micro-whisker was suggested to one of the reason resulting in the swelling phenomenon.
Comparing to the swelling phenomenon of B2 sample, the swelling may only take place along the interface between $\mathrm{Fe}$ and $\mathrm{FeO}$ in reduction of sinter. It is the reason supposed that sinter was not suffered severe swelling during reduction.

\subsection{Influence of $\mathrm{C} / \mathrm{O}$ on Reduction and Morphology Changes}

The authors suggested that $\mathrm{C} / \mathrm{O}$ ratio is an important factor when the iron ore-coal composite is used as raw material in BF. It is because the reducing agent exists not only from the coal mixed in the composite but also the upward $\mathrm{CO}$ atmosphere from the lower part of BF. Referring to the references, ${ }^{10,12,13)}$ when composite reacted under inert gas atmosphere, $\mathrm{C} / \mathrm{O}$ ratio in the range of 0.8 to 1.0 were enough to convert the reduction degree over $90 \%$. Here, the composite was subject to reduction under $\mathrm{CO}$ reducing atmosphere, it was supposed the suitable $\mathrm{C} / \mathrm{O}$ ratio was at the relative lower level.

Figure 6 shows the changes in the $\mathrm{CO}_{2}$ gas generation and $\mathrm{CO}$ gas consumption from $\mathrm{C} / \mathrm{O}=0$ to 0.6 of composite with temperature. B3 experiment was reacted under a constant of $50 \% \mathrm{~N}_{2} / \mathrm{Ar}$ atmosphere for reference. The positive and negative value of gas generation means that the gas is generated and is consumed on the basis of introduced gas, respectively. Three peaks of $\mathrm{C} 1-\mathrm{C} 4$ samples at $450-550$, 780 , and $1000^{\circ} \mathrm{C}$ are recognized as the reduction stage of hematite, magnetite and wustite, respectively. In contrast, $\mathrm{CO}_{2}$ peaks of $\mathrm{B} 3$ sample appears at 700,980 , and $1100^{\circ} \mathrm{C}$, which means that reaction under inert gas has relatively higher reduction temperature of each stage. Further, when increasing the $\mathrm{C} / \mathrm{O}$ ratio, the amount of $\mathrm{CO}$ consumption and $\mathrm{CO}_{2}$ generation at high temperature range decreases. Moreover, high $\mathrm{C} / \mathrm{O}$ ratio condition is able to lower the temperature at end point of gas generation and consumption indicated by arrow which is also recognized as the end of reduction. For example, the reduction of the $\mathrm{C} / \mathrm{O}=0.6$ sample is completed at $1100^{\circ} \mathrm{C}$, because there are nearly no $\mathrm{CO}$ consumption and therefore no $\mathrm{CO}_{2}$ generation.

When the composites were under reduction, the shape were recorded to compare the morphology changes with temperature. Figure 7 reveals the shape pictures of composite at the reduction temperature of $1200^{\circ} \mathrm{C}$ and $1300^{\circ} \mathrm{C}$. Comparing samples with the same $\mathrm{C} / \mathrm{O}$ ratio of $\mathrm{B} 3$ and $\mathrm{C} 3$, where their difference was reacted under $50 \% \mathrm{~N}_{2} / \mathrm{Ar}$ and $50 \% \mathrm{~N}_{2} / \mathrm{CO} / \mathrm{CO}_{2}$ atmosphere, the projected area of $\mathrm{B} 3$ was significantly smaller than that of $\mathrm{C} 3$. Therefore, it is sure that the $\mathrm{CO}$ and $\mathrm{CO}_{2}$ atmosphere affected the morphology changes of composite. Among the images of $\mathrm{C} / \mathrm{O}=0(\mathrm{C} 1)$, $0.2(\mathrm{C} 2)$ and $0.4(\mathrm{C} 3)$, the projected area of $\mathrm{C} 3$ was the smallest one; that of $\mathrm{C} 1$ was the largest one; that of $\mathrm{C} 2$ was under shrinkage from the top part of tablet. On the other hand, as the $\mathrm{C} / \mathrm{O}$ ratio was higher than 0.4 , the top portion of tablet turned into fluffy in the sample of C4 and C5 shown in Figs. $7(\mathrm{e})$ and $7(\mathrm{~g})$ at $1200^{\circ} \mathrm{C}$. Furthermore, when the temperature was increased, the fluffy structure shattered into powder and dropped down. Figures 7(f) and 7(h) showed the tablet collapsing into powder at $1300^{\circ} \mathrm{C}$ especially in the sample of $\mathrm{C} / \mathrm{O}=0.8$ (C5).

The reduction degree $(\mathrm{RD})$ and projected area changes (AC) in the variable of $\mathrm{C} / \mathrm{O}$ ratio with temperature were organized in Fig. 8. The key data of morphology change 
and reduction degree during the reduction of composite tablet were also pointed out in Table 4. Reference experiment B3 which was subjected to reaction under $50 \% \mathrm{~N}_{2} /$ Ar atmosphere shows that the $\mathrm{RD}$ is much lower than all $\mathrm{C}$ series samples of reacting under $50 \% \mathrm{~N}_{2} / \mathrm{CO} / \mathrm{CO}_{2}$ atmosphere. Final reduction degree is just $68 \%$, resulting from the $\mathrm{C} / \mathrm{O}=0.4$ is obviously insufficient when reaction occurs under inert gas atmosphere. However, B3 composite continuously shrinks during the reduction period. For the iron
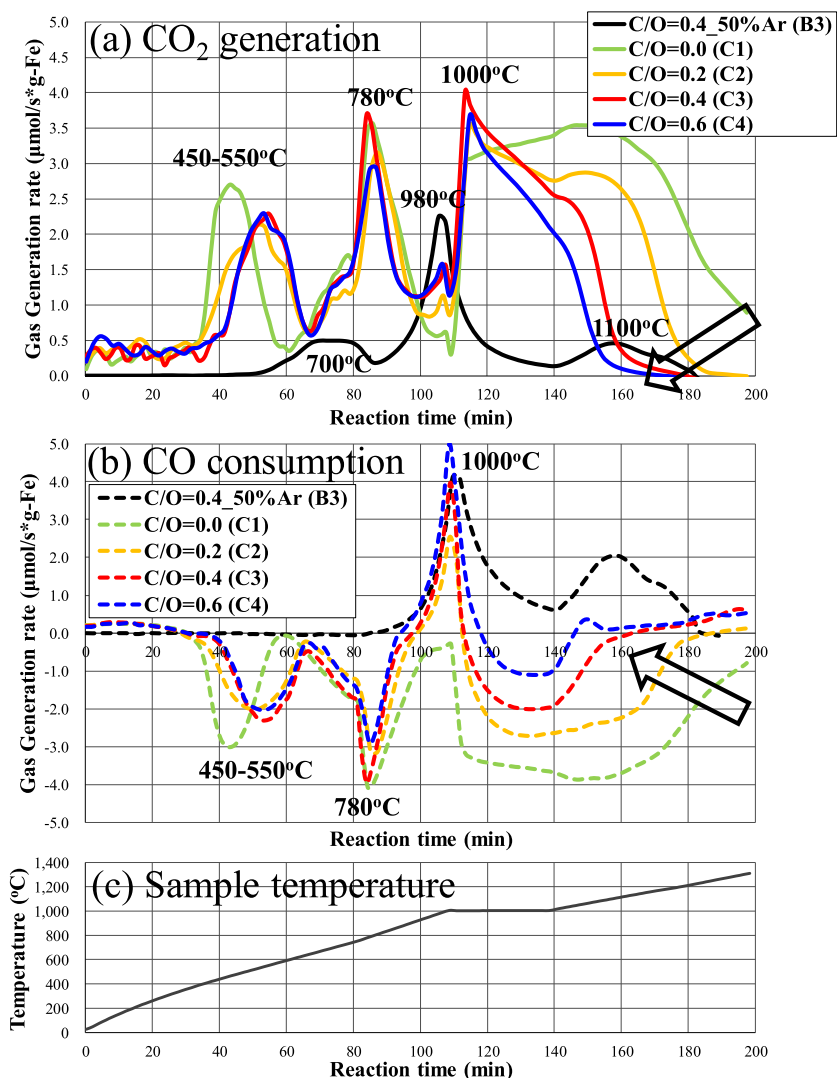

Fig. 6. Changes in the a) $\mathrm{CO}_{2}$ gas generation and b) $\mathrm{CO}$ gas consumption from $\mathrm{C} / \mathrm{O}=0$ to 0.6 of composite with c) corresponded sample temperature. B3 experiment was reacted under $50 \% \mathrm{~N}_{2} / \mathrm{Ar}$ atmosphere for reference. (Online version in color.) ore-coal composite reduced under $50 \% \mathrm{~N}_{2} / \mathrm{CO} / \mathrm{CO}_{2}$ atmosphere, straightforwardly, when increasing the $\mathrm{C} / \mathrm{O}$ ratio, the reduction rate is enhanced. Final reduction degrees are all over $90 \%$ even through $\mathrm{C} 1$ sample is without addition
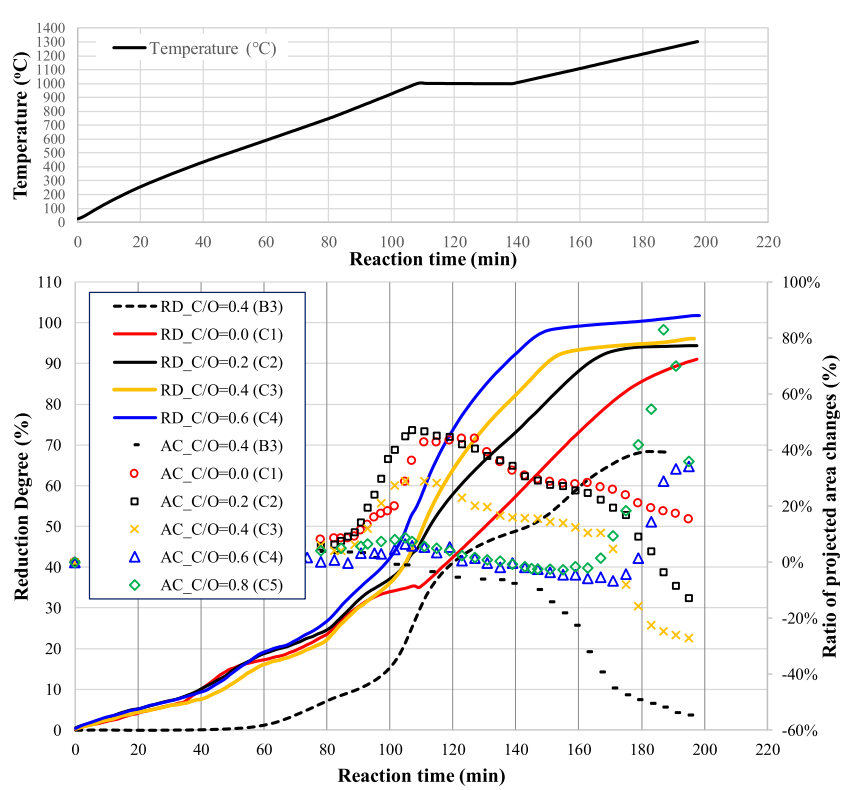

Fig. 8. The reduction degree (RD) and ratio of projected area changes $(\mathrm{AC})$ in the variable of $\mathrm{C} / \mathrm{O}$ ratio and gas atmosphere with temperature. (Online version in color.)

Table 4. Key data of morphology change and reduction degree during the reduction of composite tablet.

\begin{tabular}{lcccc}
\hline Sample name & $\begin{array}{c}\text { Maximum } \\
\text { swelling (\%) }\end{array}$ & $\begin{array}{c}\text { Collapsing } \\
\text { point }\left({ }^{\circ} \mathrm{C}\right)\end{array}$ & Final status & $\begin{array}{c}\text { Final } \\
\mathrm{RD}(\%)\end{array}$ \\
\hline $\mathrm{C} / \mathrm{O}=0.4(\mathrm{~B} 3)$ & 4 & - & $-55 \%$ shrinkage & 68 \\
$\mathrm{C} / \mathrm{O}=0.0(\mathrm{C} 1)$ & 44 & - & $15 \%$ swelling & 91 \\
$\mathrm{C} / \mathrm{O}=0.2(\mathrm{C} 2)$ & 47 & - & $-13 \%$ shrinkage & 94 \\
$\mathrm{C} / \mathrm{O}=0.4(\mathrm{C} 3)$ & 29 & - & $-27 \%$ shrinkage & 96 \\
$\mathrm{C} / \mathrm{O}=0.6(\mathrm{C} 4)$ & 7 & 1180 & Shattering & 101 \\
$\mathrm{C} / \mathrm{O}=0.8(\mathrm{C} 5)$ & 9 & 1160 & Powdering & - \\
\hline
\end{tabular}

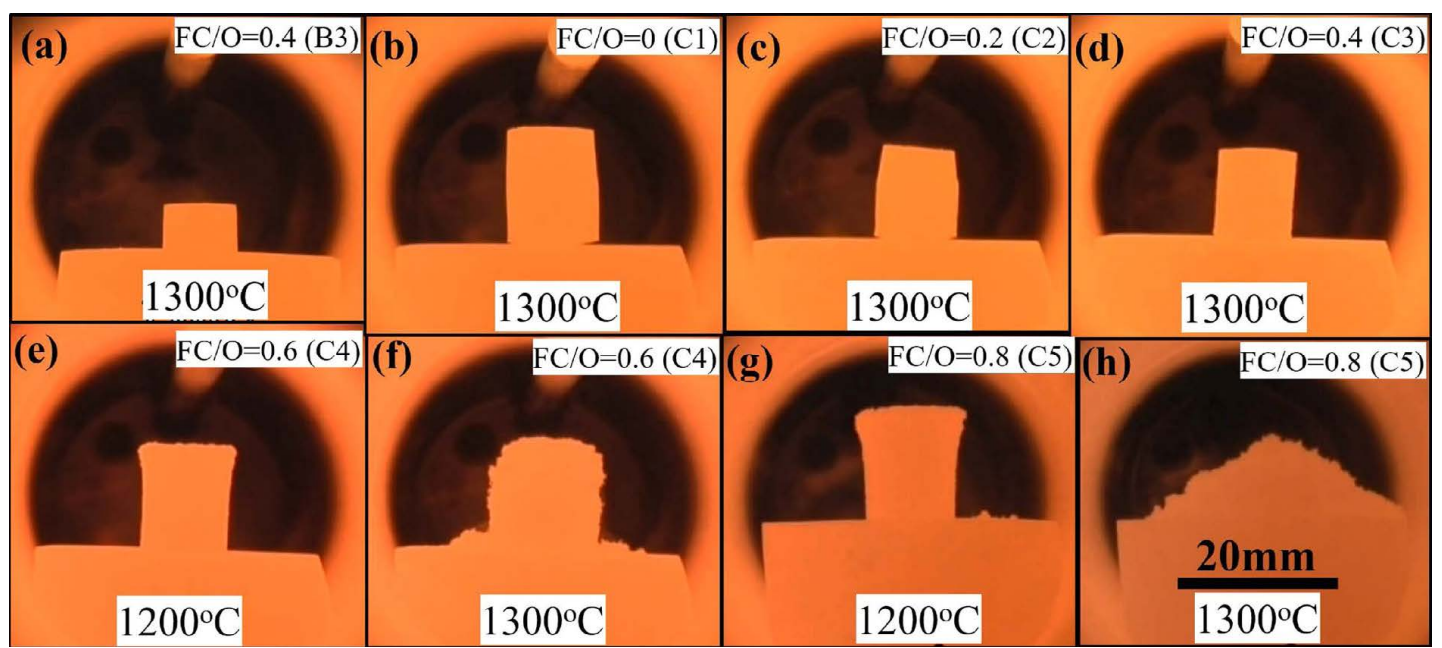

Fig. 7. Shape pictures of composite at the reduction temperature of $1200^{\circ} \mathrm{C}$ and $1300^{\circ} \mathrm{C}$. a) $\mathrm{C} / \mathrm{O}=0.4$ (B3) under $50 \% \mathrm{~N}_{2} / \mathrm{Ar}$ reaction; b-h) $\mathrm{C} / \mathrm{O}=0,0.2,0.4,0.6$ and 0.8 respectively reacted under $50 \% \mathrm{~N}_{2} / \mathrm{CO} / \mathrm{CO}_{2}$ atmosphere. (Online version in color.) 
of carbonaceous material. For the morphology changes, both composite $(\mathrm{C} 2-\mathrm{C} 3)$ and ore only $(\mathrm{C} 1)$ tablet reveals significant swelling in the temperature range of $800-1200^{\circ} \mathrm{C}$. The maximum swelling is all occurred at $1000^{\circ} \mathrm{C}$. After the temperature is higher than $1000^{\circ} \mathrm{C}$, the ratio of projected area decreases gradually until $1300^{\circ} \mathrm{C}$. As for the sample of $\mathrm{C} / \mathrm{O}=0.6(\mathrm{C} 4)$ and $0.8(\mathrm{C} 5)$, it just appears $7 \%$ and $9 \%$ of projected area changes, respectively with slight swelling at $1000^{\circ} \mathrm{C}$. Next, samples gradually shrink and nearly completed the reduction at $1100^{\circ} \mathrm{C}$. However, the ratio of projected area rapidly increases again from about $1100^{\circ} \mathrm{C}$. The subsequently swelling was derived from the fluffy structure on the top potion of tablet. According to the video recorded during the reduction, the starting temperature of collapsing were $1180^{\circ} \mathrm{C}$ and $1160^{\circ} \mathrm{C}$ of $\mathrm{C} / \mathrm{O}=0.6(\mathrm{C} 4)$ and 0.8 (C5) samples, respectively. Obviously, the shattering on $\mathrm{C} / \mathrm{O}=0.8$ sample was severer than that on $\mathrm{C} / \mathrm{O}=0.6$ sample.

In this study, samples began swelling at $800^{\circ} \mathrm{C}$ where the reduction degree was corresponded to $30-35 \%$. If the reduction of iron oxide is homogeneous and followed step by step sequence, it is suggested that most of iron oxide has already reduced to wustite and is readily converting to the next step of metallic iron. At the maximum swelling point of $1000^{\circ} \mathrm{C}$, the reduction degree reached $35-55 \%$, meaning that metallic iron partially formed. Therefore, it is proposed that the swelling was attributed to the growth of metallic iron from the reduction of wustite. As for the high $\mathrm{C} / \mathrm{O}$ ratio samples, the reduction was nearly completed at $1100^{\circ} \mathrm{C}$. Besides, referring to Fig. 6, CO consumption and $\mathrm{CO}_{2}$ generation were already stopped at $1100^{\circ} \mathrm{C}$, meaning that there were no gas pressure inside the tablet. The driving force for the shattering was not from gas pressure. The cause of shattering would be discussed latter.

$\mathrm{SEM}$ images of reduced iron in the variable of $\mathrm{C} / \mathrm{O}$ ratio and gas atmosphere are shown in Fig. 9. Figures 9(a) to 9(f) are the sectioned microstructure; Figs. $9(\mathrm{~g})$ and $9(\mathrm{~h})$ are directly observed in powder form. The microstructure of $\mathrm{C} /$ $\mathrm{O}=0.4(\mathrm{~B} 3)$ reveals a uniform phase distribution between metallic iron, $\mathrm{FeO}$ and $2 \mathrm{FeO}-\mathrm{SiO}_{2}$ (fayalite). No carbon is observed. Proposed that carbon amount of $\mathrm{C} / \mathrm{O}=0.4$ in the green composite was not enough when reduction occurred under inert gas atmosphere. Moreover, the melted fayalite combined the particles together resulting in the shrinkage of tablet. The main phase in $\mathrm{C} / \mathrm{O}=0(\mathrm{C} 1)$ sample is reduced metallic iron. There is still some part of melted fayalite phase surrounding the as-reduced metallic iron particles. In $\mathrm{C} / \mathrm{O}=0.2(\mathrm{C} 2)$ sample, most of $\mathrm{FeO}_{\mathrm{x}}$ was reduced into metallic iron. The grain of as-reduced iron is still small, and it has not yet merged together into continuous phase. Individual $\mathrm{SiO}_{2}$ grain and remained carbon are observed but not so much. When the $\mathrm{C} / \mathrm{O}$ ratio is increased to 0.4 , the reduced iron particles have been merged into continuous phase. Meanwhile, the remained carbon particles are easily observed. Usually, $\mathrm{SiO}_{2}$ grains are observed beside the carbon particle. The $\mathrm{C} / \mathrm{O}=0.6$ (C5) sample is observed in detail by both sectioned view of Figs. 9(e) and 9(f) and directly powder view of Figs. 9(g) and 9(h). Low magnification images reveal many iron particles with round shape and remained carbon particles. When zooming in the focus on the surface of iron, crack structure with high concentration
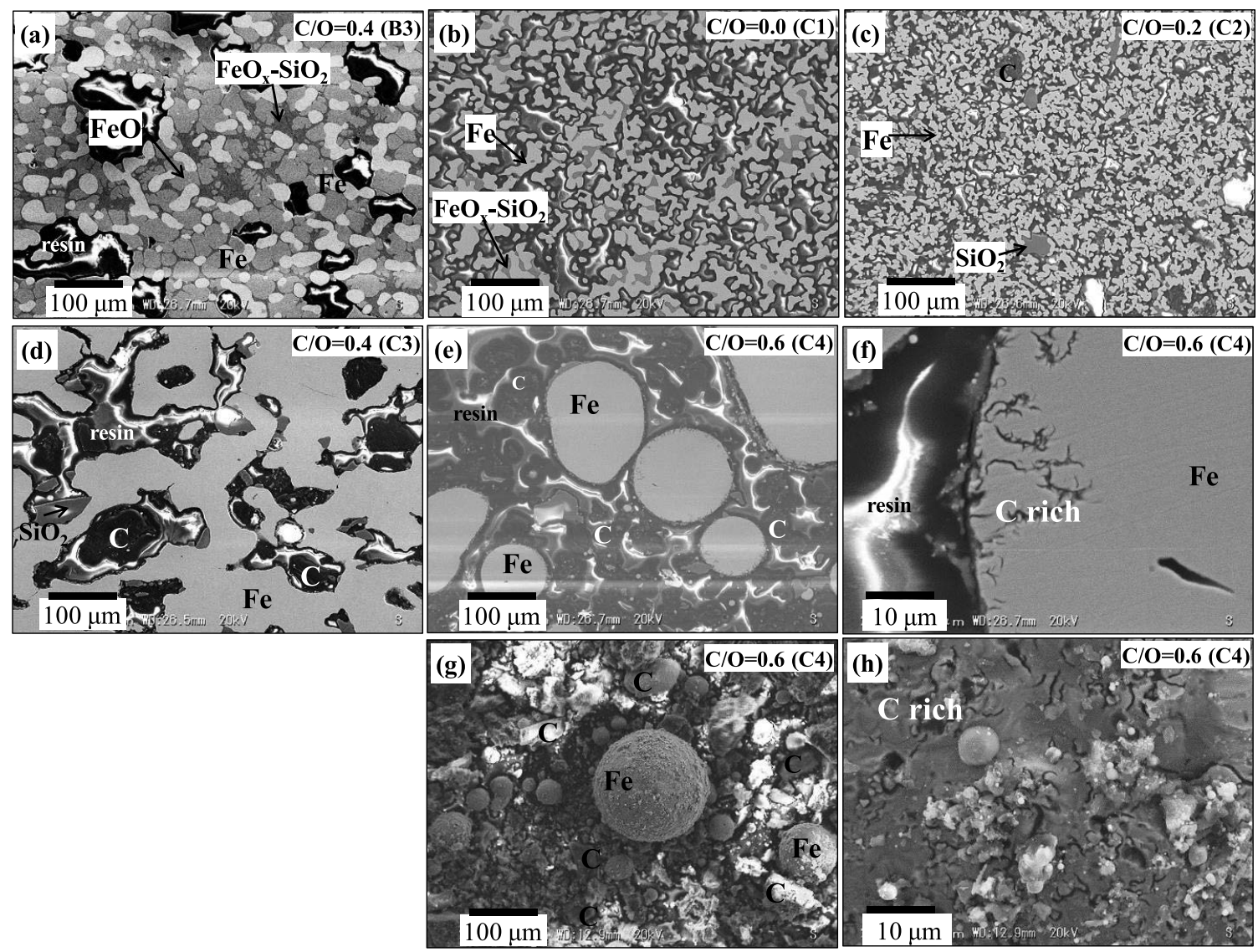

Fig. 9. SEM images of reduced iron in the variable of $\mathrm{C} / \mathrm{O}$ ratio and gas atmosphere. a) to f) were the sectioned microstructure; g) and h) were corresponding to e) and f) and were observed in powder form. 
of carbon is seen. It is suggested the carbon was precipitated to the surface during the cooling process of melted iron. In addition, some small particles attached on the surface of round shape iron was slag. Similar situation was also observed in the previous report. ${ }^{15)}$

In addition to the microstructure observation, the carbon concentration in as-reduced sample and in metallic iron were measured, individually, shown in Fig. 10. Moreover, when the total carbon is subtracted the dissolved carbon, the value stands for free carbon over the reduced iron. All of the as-reduced irons contained residual carbon, implying that the addition amount of coal in green composite was surplus for reduction under simulating the atmosphere of $\mathrm{BF}$. It is comprehensible that when increasing the $\mathrm{C} / \mathrm{O}$ ratio, the remained carbon in reduced iron are also increased. Further, carburization indeed occurred because the carbon existed in the metallic iron. The total remained carbon of $7.4 \%$ and $13.9 \%$ in mass in the reduced iron of $\mathrm{C} / \mathrm{O}=0.6$ and 0.8 , respectively, are suggested that the carbon addition was too much in both green composites. Especially, there are still 5.3 mass $\%$ and 10.5 mass $\%$ free carbon in reduced sample. It can imagine that free carbon occupied a lot of space in reduced sample because the density of carbon is much lower than that of iron. Reference reported that carbon remained in reduced iron is benefit to the carburization. ${ }^{16)}$ However, too much free carbon existed in reduced iron was likely to segregate the metallic iron particles each other rather than contacting together.

Higher $\mathrm{C} / \mathrm{O}$ ratio condition was able to accelerate the reduction of $\mathrm{FeO}_{\mathrm{x}}$ and to enhance the merging together of reduced iron particles. However, when $\mathrm{C} / \mathrm{O}$ ratio was higher than 0.4, such as 0.6 and 0.8 , the swelling, shattering and powdering behavior occurred starting from $1100^{\circ} \mathrm{C}$. According to the information of reduction degree, microstructure observation and remained carbon of reduced iron, it can be concluded that metallic iron was formed, carburization was occurred, and part of metallic iron was melted into droplets. References ${ }^{17-20)}$ reported that when

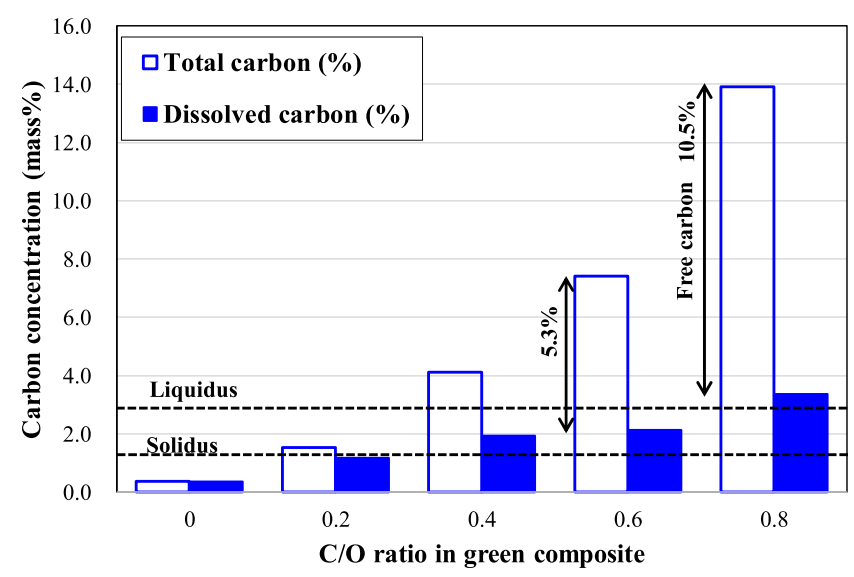

Fig. 10. Comparison of carbon concentration of reduced iron in the variable of $\mathrm{C} / \mathrm{O}$ ratio. Total carbon and dissolved carbon stand for the carbon concentration in as-reduced sample and in the metallic iron, respectively. Free carbon is the difference between total carbon and dissolved carbon. The liquidus point and solidus point at $1300^{\circ} \mathrm{C}$ of $\mathrm{Fe}-\mathrm{C}$ phase are drawn for reference. (Online version in color.) the amount of carbon dissolved in liquid iron is increased, the contact angle between liquid iron and carbon substrate is increased accordingly. In other words, the wettability is lowered as the carburization of reduced iron increases. In the cases of $\mathrm{C} / \mathrm{O}=0.6$ and 0.8 , Figs. $7(\mathrm{e})-7(\mathrm{~h})$ shows the shattering and powdering began from the surface part of reduced iron. Moreover, most of powdering materials were identified as iron droplets and free carbon particles shown in Figs. 9(e)-9(h). Therefore, supposed that the phenomenon of shattering and powdering is resulted from low wettability between iron droplets and large amount of free carbon. On the other hand, $\mathrm{C} / \mathrm{O}=0.2$ sample only remained $1.5 \%$ carbon in reduced iron. Even though all of remained carbon dissolve into iron, it seems not enough to reach the liquidus line, causing the significant decrement of melting point of iron. Of the $\mathrm{C} / \mathrm{O}$ ratio from 0 to $0.8, \mathrm{C} / \mathrm{O}=0.4$ revealed the merits of no shattering, high reduction degree and shrinkage very soon. Proposed that the amount of carbon addition at $\mathrm{C} / \mathrm{O}=0.4$ in green composite is suitable and worth to take further investigation.

According to the observation in this study, the iron orecoal composite revealed swelling during the reduction. It is indeed a drawback if composite has a significant swelling in BF. The swelling composite is highly possible to block the gas tunnel in shaft section of BF, resulting in decreasing the permeability. In fact, it is workable for improving the strength of composite by adding proper amount of binders such cement, bentonite or burnt lime in the ore-coal mixture and by spraying appropriate amount water when pelletizing. However, in our tablet preparation, the mixture powder was just directly pressed into tablet without adding water and without subject to high temperature process.

Reference ${ }^{9)}$ reported that when $10 \%$ of cement was added in the green mixture of composite and was subject to 14 days curing, the cold strength was reached 30 to $80 \mathrm{Kg} / \mathrm{cm}^{2}$ which was acceptable as a raw material of BF. Furthermore, Higuchi et al. developed a rapid curing procedure of $18 \mathrm{hrs}$ for iron ore-coal composite. That procedure included 12 hours of primary curing, 5 hours of stream curing at $80^{\circ} \mathrm{C}$ and 1 hour of drying. ${ }^{21)}$ On the other hands, Kasai et al. demonstrated that the hot briquette procedure without adding any binder also can enhance the strength of green composite. ${ }^{4,5)}$ However, comparing to the method of pan palletizer to produce the agglomerate, hot briquette procedure seems not only increasing the cost but also decreasing the production rate in the perspective of industrial production.

It is sure that using iron ore-carbon composite as raw material of $\mathrm{BF}$ is benefit to lowering the temperature of cohesive zone and decreasing the amount of reducing agent. $^{5,9)}$ This study discovered the problem on swelling of iron ore-coal composite during the temperature range of $800^{\circ} \mathrm{C}$ to $1100^{\circ} \mathrm{C}$ which was under the stage of reduction from wustite to iron. It should be clarified the root cause of swelling and then further prevent the occurrence of swelling in the following study project.

\section{Conclusions}

The investigation on reduction behavior, morphology change and carburization characteristic of iron ore-coal 
composite reacted under a similar heating profile and gas atmosphere of blast furnace was carried out by methods of an in-situ measurement of reduction gas composition and a visual observation. The results were listed as follows:

(1) The reduction rate of iron ore-coal composite was definitely higher than that of sinter and ore only tablet. As the carbon to oxygen $(\mathrm{C} / \mathrm{O})$ ratio was increased from 0 to 0.6 in composite mixture, the reduction rate was accordingly increased. $\mathrm{C} / \mathrm{O}=0.4$ was suggested to a suitable ratio. It is because when $\mathrm{C} / \mathrm{O}$ ratio was lower than 0.4 , the sample volume was swelling severe, while when $\mathrm{C} / \mathrm{O}$ ratio was higher than 0.4 , the sample became shattering starting from $1160^{\circ} \mathrm{C}$.

(2) According to the measurement of reduction rate and visual observation, the swelling of iron ore-coal composite occurred during the temperature range of $800^{\circ} \mathrm{C}$ to $1100^{\circ} \mathrm{C}$ which was under the stage of reduction from wustite to iron.

(3) On the basis of microstructure and carbon content in reduced iron, free carbon is still sufficient in $\mathrm{C} / \mathrm{O}=0.4$ reduced iron for carburization to liquids point. In contrast, the remained free carbon is surplus in $\mathrm{C} / \mathrm{O}=0.6$ and 0.8 reduced iron, causing to the shattering and powdering.

\section{REFERENCES}

1) Y. Ujisawa, K. Nakano, Y. Matsukura, K. Sunahara, S. Komatsu and
T. Yamamoto: ISIJ Int., 45 (2005), 1379

2) T. Ariyama, R. Murai, J. Ishii and M. Sato: ISIJ Int., 45 (2005), 1371.

3) M. Naito, A. Okamoto, K. Yamaguchi, T. Yamaguchi and Y. Inoue: Tetsu-to-Hagané, 87 (2001), 357 (in Japanese).

4) A. Kasai and Y. Matsui: ISIJ Int., 44 (2004), 2073.

5) A. Kasai, H. Toyota, K. Nozawa and S. Kitayama: ISIJ Int., 51 (2011), 1333.

6) A. Sato, M. Aritsuka, Y. Yamagata, T. Goto and I. Mizuguchi: CAMP-ISIJ, 5 (1992), 1064 (in Japanese).

7) S. Ueda, K. Yanagiya, K. Watanabe, T. Murakami, T. Inoue and T. Ariyama: ISIJ Int., 49 (2009), 827.

8) K. Sunahara, Y. Ujisawa, T. Murakami and E. Kasai: Tetsu-toHagané, 102 (2016), 475 (in Japanese).

9) H. Yokoyama, K. Higuchi, T. Ito and A. Oshio: ISIJ Int., 52 (2012), 2000 .

10) T. Murakami, M. Ohno, K. Suzuki, K. Owaki and E. Kasai: ISIJ Int., 57 (2017), 1928

11) P. Kowitwarangkul, A. Babich and D. Senk: Steel Res., 85 (2014), 1501.

12) H. Park and V. Sahajwalla: Metall. Mater. Trans. B, 44 (2013), 1379.

13) T. Murakami, T. Nishimura and E. Kasai: ISIJ Int., 49 (2009), 1686.

14) T. Murakami and E. Kasai: ISIJ Int., 51 (2011), 1220.

15) K. Ohno, M. Kaimoto, T. Maeda, K. Nishioka and M. Shimizu: ISIJ Int., 51 (2011), 1279.

16) T. Murakami and K. Nagata: Miner. Process. Extr. Metall. Rev., 24 (2003), 253

17) C. Wu and V. Sahajwalla: Metall. Mater. Trans. B, 29 (1998), 471.

18) R. Khanna, I. Mansuri and V. Sahajwalla: Wetting and Wettability, ed. by M. Aliofkhazraei, IntechOpen, London, (2015), 357.

19) K. Ohno, T. Miyake, S. Yano, C. S. Nguyen, T. Maeda and K. Kunitomo: ISIJ Int., 55 (2015), 1252.

20) C. S. Nguyen, K. Ohno, T. Maeda and K. Kunitomo: ISIJ Int., 57 (2017), 1491.

21) K. Higuchi, H. Yokoyama, H. Sato, M. Chiba and S. Nomura: ISIJ Int., 57 (2017), 55 